DOI: https://doi.org/10.32839/2304-5809/2021-11-99-7

удК 323.39

Coxa C.C.

Київський національний університет імені Тараса Шевченка

\title{
ВПЛИВ ЕЛІТ НА ДЕРЖАВНЕ УПРАВЛІННЯ В УКРАЇНІ
}

Анотація. У даній статті вирішено актуальне наукове завдання, що полягає в науковому обгрунтуванні моделі впливу еліт на державне управління в Україні з метою підвищення їх якості й ефективності діяльності. Обгрунтовано сутність еліт, визначено, що еліти розуміються, як сощіальна страта, що включає людей з підвищеною соціальною активністю, які беруть участь у прийнятті рішень. Проаналізовано вплив еліт та визначено їх основну роль. Запропоновано створити нову модель політико-управлінської еліти в Україні, створити систему трансформації, використовуючи на практиці досвід країн Європи. Об'єкт дослідження - суспільні відносини, які виникають в процесі впливу еліт на державного управління. Предмет дослідження - вплив еліт на державне управління в Україні.

Ключові слова: державне управління, публічне адміністрування, публічне управління, механізм впливу, еліта, політична еліта, політико-управлінська еліта.

Sokha Semen

Taras Shevchenko National University of Kiev

\section{INFLUENCE OF ELITES ON PUBLIC MANAGEMENT IN UKRAINE}

Summary. This article solves the current scientific problems that are in the scientific substantiation of models of elite influence on public administration in Ukraine in order to improve their quality and efficiency. The essence of elites is substantiated, it is determined that today elites understand as a social stratum, which includes people with increased social activity, who participate in the perception of socially significant decisions and the use of a wide variety of methods. The influence of elites is analyzed and formulated so that the main elite is to set an example, an example of how to live, how to behave morally in human situations, how to create a culture in society for a decent life - an elite culture to make all the world human relations the best, kind, creative, in a word, society for people. It is proposed to create a new model of political and managerial elite in Ukraine, to create a system of transformation, using in practice the experience of European countries. The main direction of application of such experience is the formulation of the national idea, ensuring the openness of the political and managerial elite and meritocratic principles of personnel policy, the creation of a system of elite education. One of the important factors influencing the course of political and social development of public administration is the existence of an established system of elite representatives and its activities. The political elite means a social structure that includes people with increased social activity, who are directly involved in making socially significant decisions and use different methods for this, based on their profession, power status, personal qualities.

Keywords: state administration, public administration, public management, mechanism of influence, elite, political elite, political and managerial elite.

Постановка проблеми. Сьогодні у всьо1 му світі відбуваються процеси глибокої трансорормації, редормування та оновлення таких глобальних понять, як держава і процеси державного управління. В таких умовах вирішального значення набуває процес формування ефрективної та результативної системи державного, управління, адекватної українським реаліям і світовим тенденціям. У цих умовах, недостатня адаптованість політичної еліти та їі лідерів до соціально-політичних змін у сучасному українському суспільстві та світі загалом є одним із чинників, які стримують процесу модернізації.

Аналіз останніх досліджень і публікацій. Проблема еліт у науці упродовж тривалого часу розглядаються різними авторами. Загалом виникнення теорії еліт в України зазвичай пов'язують 3 іменами вчених В. Липинського та Д. Донцова. Окрім цього, на проблеми еліт звертали увагу такі вчені, як І. Лисяк-Рудницький, Г. Грабович, Я. Пеленський. На сучасному етапі, дослідженням проблеми еліт у тому чи іншому контексті займалися такі сучасні науковці, як Г. Ашин, С. Вовканич, Б. Гаврилишин, В. Голубь, І. Лопушинський, А. Колодій, Б. Кух та, В. Лизанчук та інші.
Виділення не вирішених раніше частин загальної проблеми. Попри дослідницьку активність у зазначеному напрямі, проблема впливу еліти на механізм державного управління, зокрема особливості їі становлення і розвитку ще не є достатньо розробленими, а відповідні напрацювання впровадженими в практику державного управління в Україні. Ще й досі не чітко не визначено сутність еліт та їх впливу на здійснення державного управління, особливості впливу еліт на владу на різних етапах історичного розвитку суспільства, особливості вітчизняних еліт i ï здатність впливати на фрункціонування органів виконавчої влади, не запропоновано основні організаційні форми та засоби едективного впливу еліт на державне управління.

Мета статті обгрунтування теоретичних положень та розроблення практичних рекомендацій щодо вдосконалення механізму впливу еліт на державне управління в Україні.

Виклад основного матеріалу. Вагомий внесок у розвиток поняття еліт було зроблено німецьким дослідником М. Вебером. Він започаткував концепцію "демократичного елітизму» та був упевнений, що будь-яка влада здійснюеться угрупованням вождів, і тому народ має справ- 
жню можливість управляти тільки в системі безпосередньої демократії. У великих - народ сам по собі, як неорганізована аморфна маса, правити не може, це роблять від його імені окремі керівники [2, с. 68]. Одне з основних положень його конщепції, згідно з яким чисельність і вплив бюрократії, як соціального прошарку, буде неминуче зростати в міру ускладнення фрункцій держави, набуває особливої актуальності і в наші дні. Боротьбу між політичними партіями і бюрократичним апаратом він вважав основним конфрліктом політичної системи [2, с. 68].

Досить поширеним є трактування ідей елітизму з точки зору психологічного підходу. На думку 3. Фрейда, більшості суспільства притаманні антисуспільні й антикультурні тенденції в поведінці, що провокують виникнення соціальної напруги. Відповідно, в суспільстві існуе поділ на більшість, якою потрібно постійно управляти, та меншість, яка завдяки своїй організованості та структурованості може застосовувати різні засоби впливу. Такий поділ виникає на основі існуючого в людині потягу до підкорення батьківському авторитету [10, с. 5].

И. Шумпетер поєднав поняття елітаризм з прихильністю демократії, обгрунтувавши ідею про те, що еліти, панівні «демократичним шляхом», шляхом виборів i конкуренції, повинні розглядатися як невід'ємний елемент сучасних розвинутих суспільств [2, с. 67]. Й. Шумпетер говорив, що демократія $є$ не здійснення «волі народу», а процедура, методів прийняття рішень, при якому індивіди отримують право приймати рішення шляхом конкурентної боротьби заголоси виборців [10, с. 5].

Загалом же поняття еліт розглядається в декількох напрямах серед, яких ірраціональний, біологічний, психологічний теократичний.

Поняття еліт у сучасному розумінні зазнало значних трансформацій, і має роздвоєність. Проте, для входження в еліту слід відповідати певному набору вимог, властивих тим чи іншим політичним системам в конкретний період часу.

Основна роль еліти будь-якої сфрери суспільно-політичної діяльності давати взірець, приклад того, як жити, як морально вести себе в людських ситуаціях, як творити в суспільстві культуру для гідного життя людей - елітарну культуру, щоб для усіх зробити світ людських відносин кращим, добрішим, творчим, словом, суспільством для людей [2, с. 6]. Адже, сорормована еліта є одним із важливих компонентів формування політичної системи держави, високого рівня авторитету серед інших країн та процесів соціальних змін, формування національної культури та самосвідомості.

Серед дослідників поняття еліт не існуе єдиного визначення даного явища. Поняття еліт зазнало значних трансформацій та накопичило міцну методологічну основу. На сьогоднішній день еліти розуміються, як соціальна страта, що включає людей 3 підвищеною соціальною активністю, які беруть безпосередню участь у прийнятті суспільно значимих рішень та використовують для цього велике розмаїття методів [2, с. 13].

На нашу думку, під управлінською елітою можливо мати на увазі державних службовців органів влади. Це особи які займають управлінські посади в органах законодавчої виконавчої та судової влади. При цому такі особи не займають виборні посади. Особи яких обирають $є$ представниками політичної а не управлінської еліти хоча між цими категоріям є багато спільних рис. Засоби впливу представників еліт залежать від наявності певних владних повноважень відповідної закріпленої посади.

Окрім політичних та владних еліт, сощіологи окремо виділяють також економічні еліти [3]. Складність проблеми економічної еліти полягає в тому, що це поняття має різне значення (а саме, за умов соціально-політичної економіки й за ринкової ситуації). Якщо в першому випадку до ціеї групи входять ті, хто приймае найважливіші рішення щодо фрункціонування та розвитку національної економіки (без приватної власності), то за ринкової економіки з приватною власністю, економічна еліти це ті, хто приймає найважливіші рішення 3 питань економіки, також до них відносяться і великі власники.

Соціальне призначення політичних еліт переважно проявляеться у фрункціях, які вони виконують у суспільстві [9, с. 402]. Ці фрункції різноманітні і тісно пов'язані з політичною системою всього суспільства, його підсистемами, функціями, які виконують різні інститути.

Також дослідники вважають, що головними функціями політичної еліти є наступні: політичне цілепокладання; владно-політична інтеграція суспільства; регулювання режиму соціально-політичної діяльності; мобілізаційна фрункція; вираження і представництво в політичній системі суспільства соціальних інтересів; комунікативна функція [9, с. 401].

На нашу думку, основна роль еліти будь-якої сорери суспільно-політичної діяльності давати взірець, приклад того, як жити, як морально вести себе в людських ситуаціях, як творити в суспільстві культуру для гідного життя людей - елітарну культуру, щоб для усіх зробити світ людських відносин кращим, добрішим, творчим, словом, суспільством для людей.

На нашу думку державно-управлінська та політична еліта $є$ взаємопов'язаними категоріями. Для здійснення управління державою на належному рівні необхідно мати надзвичайні психологічні, соціальні та політичні якості, володіти певними знаннями та навичками для підготовки, ухвалення та виконання рішень, пов'язаних із використанням державної влади чи впливу. Отже, мова йде про «політичні еліти», включаючи вищу структуру управління з усіх гілок державної влади, які приймають закони та інші нормативні акти, втілюють у життя плани та положення, керують основними політичними інститутами суспільства.

Однак, при цьому, якісні характеристики верхнього ешелону українського суспільства викликають певні занепокоєння [8, с. 277]. Представники українських політичних еліт навчилися боротися за владу, але, з різних причин, не завжди можуть розпорядитися цією владою в інтересах суспільства.

Представники еліти, як учасники державотворчого процесу, мають вагомий вплив на перебіг подій у суспільстві, визначають соціальні настрої, формують підгрунтя розвитку національної свідомості, формують творчу та культурну спадщину для майбутніх поколінь. 
На нашу думку, з втратою державою своїх владних позицій під час перехідного процесу політична та управлінська еліти України втратили свої позитивні якості. Використання традиційних та досить ефективних засобів і методів соціального управління дає можливість еліті здійснювати не формальну, але фактичну владу в приватизаційних та інших процесах [7, с. 91]. На нашу думку, дисбаланс влади та функцій, а також не властиві еліті масштаби владних повноважень, в умовах трансформації, призвів до втрати своєї ефективності.

Окремі відмінності криються у колі посад які можуть займати представники державно-управлінської еліти - це посади в органах виконавчої влади на які здійснюеться призначення та політична еліта вже займає виборні політичні посади. Діяльність еліти оріентуеться на відкритості управління та ефрективній реалізації управлінських завдань. Для системи управління в трансформованому суспільстві використання неперевірених або суперечливих методів $є$ надзвичайно шкідливим і може завдати шкоди стабільності системи. Ефективність застосування тих чи інших методів і прийомів залежить від характеру обраної моделі. У зв'язку з цим найбільш прийнятною буде така модель розвитку політичних та управлінських еліт, яка дозволяе врахувати управлінський досвід конкретної країни та нові тенденції соціального управління.

Як приклад, окремі категорії населення вже почали усвідомлювати свої особисті інтереси. Беручи участь у всесвітньому демократичному русі, необхідно здійснювати спільні дії в підприемницькому середовищі з метою покращення умов для розвитку бізнесу. Підприемці брали участь у виборах 1989-1999 років і змогли таким чином частково інтегруватись до політичної та державно-управлінської еліти. Це був перший крок, зроблений представниками нової економіки на політичній арені, намагання заявити суспільству про свое існування.

Бізнес часто використовуе таку форму політичного лобіювання, яку можна назвати технічним лобізмом. Йдеться про вплив на фрахівців, експертів та вищих чиновників, які беруть участь у розробці законів та прийнятті політичних [3, с. 4]. Саме через експертів (багато з яких мають пряме чи опосередковане ставлення до бізнес-структур) компанії можуть коригувати прийняті закони.

Поряд 3 «груповими» спробами впливати на політику, підприемці використовують особисті стосунки, щоб чинити тиск на рішення, прийняті через урядовців. Але в такому випадку йдеться не про створення сприятливих умов для розвитку бізнесу, а про надання вигідніших умов конкретній комерційній структурі.
Існують дві моделі політичної поведінки в підприемницькому середовищі. Перша модель спрямована на особисту участь підприемців у політиці, при чому, ступінь залученості до політичного процесу може відрізнятися. Так, наприклад, деякі готові пожертвувати своєю діяльністю у сфері бізнесу та піти у велику політику (такі складають меншість) [3, с. 5]. Тому, на нашу думку, проте саме вони стають центром політичних партійних кадрів та осередком активістів, які регулярно беруть участь у партійній діяльності.

3 часом деякі з них стають професійними політиками, відстоюючи інтереси свого класу на національному рівні. Але для більшості політично активних бізнесменів підтримка політичних партій набувае форми співчуття. Серед тих, хто симпатизуе політичним партіям, $є$ представники бізнесу, які продовжують займатися професійною діяльністю. Вони е соціальною основою політичної партії, підтримують її на виборах та надають матеріальну допомогу.

Так, наприклад, у часи кризи підприемці будь-якого масштабу готові долучитися до політичної боротьби. Однак, коли суспільно-політична ситуація стабілізувалася, середній підприемець повертається у сферу своеї фрахової діяльності [3, с. 6].

3 нашої точки зору, політична діяльність економічних еліт насамперед пояснюється їх економічними можливостями. Великий капітал може використовувати широкий спектр непрямих форм політичної дії. Зі зменшенням ресурсів поле політичної участі звужуеться. Порівняння моделей політичної поведінки показуе, що різні представники бізнесу мають власні пороги участі в політичній діяльності.

Висновки й пропозиції. Таким чином можна зазначити що політична та управлінська еліти мають значний вплив на розвиток державотворення та державного будівництва. При цьому, фактично через політичну еліту здійснюеться легітимація органів державного управління, i, займаючи адміністративні та виборні посади представники еліти мають можливість домогтись забезпечення розвиту державних інституцій та механізмів.

Політичні та управлінські еліти відіграють ключову роль у процесі демократичного транзиту та визначають національні стратегії та тактики розвитку. Тому створення корпусу еліт для державного управління та відбір, навчання й використання професійних кадрів е запорукою політичної стабільності та соціального процвітання. Реалізація поставленого завдання може відбуватися шляхом впровадження в практику науково-обтрунтованих кадрових технологій та механізмів елітної інженерії.

\section{Список літератури:}

1. Головатий М. Політична еліта сучасної України: регіональний і національний контекст. Політичний менеджмент. 2006. С. 42-48.

2. Елітознавство : підручник / за заг. ред. В. А. Гошовської. 2013. 268 с.

3. Запорожець Т. В. Економічна еліта у політичному полі україни. Проблеми і результати дослідження. 2005. URL: http://www.dy.nayka.com.ua/pdf/11_2015/9.pdf (станом на 23.11.2021 року).

4. Кислова О. Н., Лисиця Н.М., Скориніна О.В. Стратегии формирования элиты. Стратегія розвитку Украӥни (еконоліка, соціологія, право) : наук. журнал. 2004. С. 569-577.

5. Корнієнко В. О., Похило І. Д. Ефективність політичного лідера: критерії та механізми реалізації в сучасній Україні : монографрія. Вінниця : ВНТУ, 2009. 140 с. 
6. Крюков О. Демократизація суспільства та розвиток еліти. Вісник НАДУ. 2004. № 4. С. 470-475.

7. Крюков О. І. Політико-управлінська еліта України як чинник державотворення : монографрія. Київ : Вид-во НАДУ, 2006. $252 \mathrm{c.}$

8. Сахань О. М., Мельник І. Л. Політична еліта україни: сучасний стан і перспективи. Актуальні проблели державного управління. 2012. № 2(42). С. 275-282.

9. Шляхтун П. П. Політологія: історія та теорія : підручник. Київ : Вид-во Либідь, 2005. 576 с.

10. Радченко А. П. Концептуалізація поняття політикоуправлінська еліта в умовах трансформації системи державного управління. URL: http://www.dy.nayka.com.ua/pdf/7_2018/101.pdf

11. Томашевська Т. В. Формування політико-управлінської еліти в Україні: функціонально-компетентнісний підхід. URL: http://academy.gov.ua/pages/dop/137/files/b5151edf-a2f9-498f-808b-291223cf4fc0.pdf

\section{References:}

1. Holovatyi M. (2006) Political elite of modern Ukraine: regional and national context. Politychnyi menedzhment, Spetsialnyi vypuck, pp. 42-48.

2. Elitoznavstvo: pidruchnyk (2013) / za zah. red. V. A. Hoshovskoi. Kyiv: NADU, 268 p. [Elite studies].

3. Zaporozhets T. V. (2015) Ekonomichna elita u politychnomu poli ukrainy. Problemy i rezultaty doslidzhennia [The economic elite in the political field of Ukraine. Problems and results of the study]. Available at: http://www.dy.nayka.com.ua/pdf/11_2015/9.pdf

4. Kyslova O. N., Lysytsia N. M. and Skorynina O. V. (2004) Strategics of forming of elite. Stratehiia rozvytku Ukrainy (ekonomika, cotsiolohiia, pravo): nauk. zhurnal, no. 1-2, pp. 569-577.

5. Korniienko V. O. (2009) Efektyvnist politychnoho lidera: kryterii ta mekhanizmy realizatsii v suchasnii Ukraini: monohrafiia [The effectiveness of a political leader: criteria and mechanisms of implementation in modern Ukraine: a monograph]. Vinnytsia: VNTU.

6. Kriukov O. (2004) Democratization of society and development of elite. Vicnyk NADU, no. 4, pp. 470-475.

7. Kriukov O. (2006) Politiko-administrative elite of Ukraine: features of becoming and development are in the conditions of public transformation, Ph.D.: monograph. State administration, A national academy of state administration is at President of Ukraine. Kyiv: Vyd-vo NADU.

8. Sakhan O. M., Melnyk I. L. (2012) Politychna elita Ukrainy: suchasnyi stan i perspektyvy [Ukraine's political elite: current state and prospects]. Aktualni problemy derzhavnoho upravlinnia, no. 2(42), pp. 275-282.

9. Shliakhtun P. P. (2005) Politolohiia: istoriia ta teoriia: Pidruchnyk [Political Science: History and Theory]. Kyiv: Lybid, $576 \mathrm{p}$.

10. Radchenko A. P. (2018) Kontseptualizatsiia poniattia politykoupravlinska elita v umovakh transformatsii systemy derzhavnoho upravlinnia [Conceptualization of the concept of political and managerial elite in the conditions of transformation of the system of public administration]. Available at: http://www.dy.nayka.com.ua/ pdf/7_2018/101.pdf

11. Tomashevska T. V. (2021) Formuvannia polityko-upravlinskoi elity v Ukraini: funktsionalno-kompetentnisnyi pidkhid [Formation of political and managerial elite in Ukraine: functional-competence approach]. Available at: http://academy.gov.ua/pages/dop/137/files/b5151edf-a2f9-498f-808b-291223cf4fc0.pdf 